\title{
FATTY ACID COMPOSITION OF CANE MOLASSES AND YEASTS
}

\author{
L.E.GUTIERREZ; R.C.M.DA SILVA \\ Departamento de Qutmica, ESALQ/USP, C.P. 9, CEP: 13418-900-Piracicaba-SP, Brasil
}

\begin{abstract}
Lipid extract and fatty acid composition of cane molasses and yeasts (Saccharomyces cerevisiae M-300A and Saccharomyces uvarum IZ-1904) grown in molasses medium were determined. In molasses, linoleic acid was found in higher levels (around $42 \%$ ) and was followed by palmitic, oleic and linolenic acids. The lipid extract varied from 1.02 to $3.13 \mathrm{gkg}^{-1}$. In yeasts, the level of lipid extract varied from 16.65 to $31.12{\mathrm{~g} . \mathrm{kg}^{-1}}^{\text {(dry matter basis) }}$ depending on the molasses type and yeast species. Both yeasts were able to incorporate fatty acids from molasses' and therefore linoleic and palmitic acids were the major fatty acids found in them.
\end{abstract}

Key Wonds: Saccharomyces, fatty acids, yeasts, lipids, molasses.

\section{COMPOSIÇĀO EM ÁCIDOS GRAXOS DE MELAÇO DE CANA-DE-AÇUCAR E DE LEVEDURAS}

RESUMO: Foram determinados o extrato lipídico e a composiçāo em ácidos graxos de melaço de cana-de-açúcar e das leveduras (Saccharomyces cerevisiae M-300-A e Saccharomyces uvarum Iz-1904) multiplicadas em meio fermentativo de melaço. Nos melaços, o ácido linoleico foi encontrado em maiores quantidades (cerca de $42 \%$ do total) e foi seguido pelos ácidos palmítico, oleico e linolênico. $O$ extrato lipídico variou de 1,02 até $3,13 \mathrm{~g} \cdot \mathrm{Kg}^{-1}$. Em leveduras, o nível do extrato lipídico variou de 16,65 ate $31,12 \mathrm{~g} \cdot \mathrm{kg}^{-1}$ (com base na matéria seca) e foi afetado pelo tipo de melaço e da espécie de levedura. Ambas as leveduras foram capazes de incorporar ácidos graxos presentes no melaço e portanto os ácidos linoleico e palmítico foram os principais ácidos graxos encontrados nessas leveduras.

Descritores: Saccharomyces, ácidos graxos, lipídios, melaço, leveduras

\section{INTRODUCTION}

In the Melle-Boinot process of ethanol production used in Brazil, a small amount of yeast can be removed without affecting ethanol yield (ORELLI et al., 1991) and the yeast can be used in livestock feeds as recommended to swine by BOWMAN \& VEUM (1973), to poultry by VANANUVAT (1977) and to cattle by JARDIM (1976), due to the excellent contents of protein and B group vitamins (HARRISON, 1971). Cane molasses, another by-product of sugar factories is also used as animal feed due to its high level of energy and minerals (MORRISON, 1959).

Domestic animals are not able to synthetize linoleic acid (SHORLAND,1962) and need, therefore, to obtain this acid from feed. Linoleic and other essential fatty acids deficiencies are characterized by skin symptoms and are best documented by laboratory rat tests (GURR, 1984).

The yeasts normally used for ethanol production in distilleries are not able to produce polyusaturated acids as linoleic and linolenic, but do produce palmitoleic and oleic acids (NAGARLEGMANN \& MARGALITH,1987; BENDOVÁ et al., 1991). They can however take up fatty acids from the medium (REZENDE \& ALTERTHUM, 1986).

Therefore, the fatty acid composition of the yeasts used in distilleries can reflect molasses composition. Linoleic acid is the most important fatty acid in Louisiana sugarcane (BALCH, 1953) and in Hawaii cane molasses (MEE et al., 1979). There is no available data for Brazilian sugarcane molasses.

This paper deals with the fatty acid composition of cane molasses and yeasts grown in their medium.

\section{MATERIALS AND METHODS}

Cane molasses. Molasses samples were collected from nine sugar factories in the State of São Paulo (Brazil) containing 500 to $600 \mathrm{~g} \cdot \mathrm{kg}^{-1}$ of total reducing sugars. 
Fatty acids from molasses. $10 \mathrm{~g}$ of molasses were diluted with $10 \mathrm{ml} 0.25 \mathrm{NH}_{4} \mathrm{Cl}$ and shaken twice with $45 \mathrm{ml}$ of chloroform: methanol solution $(2: 1 \mathrm{v} / \mathrm{v})$ as recommended by FOLCH et al. (1957). The combined extracts were washed with $9 \mathrm{~g} \cdot \mathrm{l}^{-1} \mathrm{NaCl}$. The chloroform layer was evaporated to dryness at $55^{\circ} \mathrm{C}$ under vaccum. The residue was reextracted with petroleum ether, washed with water and evaporated at $40^{\circ} \mathrm{C}$ under vaccum.

Yeast growth. The yeasts Saccharomyces cerevisiae M-300-A and Saccharomyces uvarum IZ1904, industrially used in Brazil for ethanol production, were grown anaerobically in molasses medium with $150 \mathrm{~g}^{-1}$ of total reducing sugars at $33^{\circ} \mathrm{C}$. $1.0 \mathrm{~g} . \mathrm{l}^{-1}\left(\mathrm{NH}_{4}\right)_{2} \mathrm{SO}_{4}$ and $0.5 \mathrm{~g} . \mathrm{l}^{-1} \quad \mathrm{KH}_{2} \mathrm{PO}_{4}$ were added as a nutrient supplement to the yeasts. The yeasts were washed three times with cold water before lipid extraction.

Fatty acids from yeasts. $6 \mathrm{~g}$ of yeast cells were treated with $10 \mathrm{ml} 0.25 \mathrm{NH}_{4} \mathrm{Cl}$ at $70^{\circ} \mathrm{C}$ during 15 min. After cooling, $60 \mathrm{ml}$ of chloroform were added: methanol mixture $(2: 1 \mathrm{v} / \mathrm{v})$, according to FOLCH et al. (1957) and left overnight at room temperature. After centrifugation the yeast pellet was reextracted and the combined extracts washed with 9 g. $1^{-1} \mathrm{NaCl}$ solution. The chloroform layer was evaporated at $55^{\circ} \mathrm{C}$, under vaccum.

Fatty acids analysis. The methyl esters of fatty acids were obtained according to HARTMAN \& LAGO (1973). They were analysed in CG-17 Gas Chromatograph (CG Instruments, São Paulo, Brazil), equipped with flame ionization detector and $2 \mathrm{~m} \times 0.5 \mathrm{~cm}$ coiled stainless steel column packed with $18 \%$ DEGS on 100 mesh Chromosorb $\mathrm{W}$. The oven temperature was $180^{\circ} \mathrm{C}$ and both, injector and detector were operated at 230 and $240^{\circ} \mathrm{C}$, respectively. Fatty acids were identified by the comparison of their retention times with those of the pure compounds and by the equivalent chain length (ACKMAN, 1962). All measurements were made in triplicate and all the reagents were of analytical grade. The triangulation method was used to determine the corresponding peak areas. The fatty acid composition was calculated by multiplying each peak-area percentage by the corresponding mol wt of the fatty-acid methyl ester and, subsequently, dividing each product by the sum of the weighted products.

\section{RESULTS AND DISCUSSION}

Table 1 shows that all the molasses have the same fatty acids in the following order: linoleic, palmitic, oleic, linolenic, stearic and other minor acids. These results show the presence of linolenic acid which was also reported by BALCH (1953) in Louisiana sugarcane, but was not detected by MEE et al. (1979) for Hawaii cane molasses. The lipid extract in molasses varied from 1.02 to $3.13 \mathrm{~g} / \mathrm{kg}$. These variations may be due to the extent of sucrose extraction in different sugar factories. The results of lipid extract were lower than those related by MEE et al. (1979), perhaps because they did not purify the chloroform extract with petroleum ether as it was performed in this experiment. The level of linoleic acid in molasses is considered adequate for yeast growth (GUTIERREZ, 1991). THOMAS \& ROSE (1979) and GUTIERREZ (1990) reported that linoleic acid gives more protection to yeast membrane against ethanol.

Tables 2 and 3 indicate that the industrially used yeasts were able to absorb and incorporate fatty acids from molasses. It can be observed that the level of lipid extract of molasses affects the lipid extract and fatty acid composition of yeasts. The presence of exogenous fatty acids reduces short-fatty acid contents, confirming carly observations of GUTIERREZ (1991).

Fatty acid profiles from yeasts indicate that the major components were linoleic and palmitic acids. Besides being good source of B vitamins the yeasts grown in cane molasses also for poultry because hens require about $1 \%$ of linoleic acid in their diet (BONDI,1987) to meet their needs for most production purposes. The yeasts in anaerobic medium can synthetize fatty acids mainly palmitic acid (SUOMALAINEN \& KERANEN, 1963) but the presence of linolcic acid in the molasses medium inhibits the dessaturation of palmitic acid (BLOOMFIELD \& BLOCH, 1960). This can be observed for both yeasts (Tables 2 and 3) grown in molasses number nine that shows high level of linoleic and low palmitoleic acid contents.

The desired level recommended for animals is not yet known, however around $1 \%$ of dietary energy as linoleic acid could prevent the symptoms of essential fatty acids deficiency (GURR, 1984).

The amount of lipid extract in molasses and yeasts is not enough to attend animal requirements as the only fatty acid source. 
TABLE 1 - Lipid extract (g.kg-1) and fatty acid composition of several cane molasses.

\begin{tabular}{cccccccccc}
\hline & \multicolumn{10}{c}{ Molasses } \\
\cline { 2 - 9 } Fatty Acid* & 1 & 2 & 3 & 4 & 5 & 6 & 7 & 8 & 9 \\
\hline $12: 0$ & 0.5 & 0.5 & 0.5 & 0.3 & 0.5 & 0.3 & 0.4 & 0.6 & 0.4 \\
$14: 0$ & 0.3 & 0.3 & 0.5 & 0.3 & 0.4 & 0.2 & 0.3 & 0.3 & 0.3 \\
$14: 1$ & 0.6 & 0.4 & 0.4 & 0.5 & 0.5 & 0.5 & 0.6 & 0.4 & 0.6 \\
$16: 0$ & 32.7 & 31.1 & 31.1 & 31.7 & 30.1 & 31.6 & 30.8 & 30.2 & 30.4 \\
$16: 1$ & 0.2 & 0.3 & 0.4 & 0.4 & 0.3 & 0.2 & 0.4 & 0.3 & 0.4 \\
x & 0.1 & 0.1 & 0.1 & 0.1 & 0.2 & 0.2 & 0.1 & 0.1 & 0.1 \\
$18: 0$ & 1.9 & 1.9 & 2.1 & 2.0 & 2.0 & 2.1 & 2.1 & 2.0 & 2.2 \\
$18: 1$ & 10.8 & 11.6 & 11.0 & 11.4 & 12.5 & 11.5 & 12.6 & 12.3 & 13.0 \\
$18: 2$ & 41.8 & 42.2 & 43.1 & 42.1 & 42.3 & 41.9 & 41.6 & 42.3 & 41.6 \\
$18: 3$ & 11.2 & 11.6 & 10.8 & 11.2 & 11.1 & 11.4 & 10.9 & 11.4 & 10.9 \\
\hline lipid extract & 1.73 & 2.15 & 1.02 & 2.06 & 1.74 & 2.05 & 2.36 & 2.04 & 3.13 \\
\hline \hline
\end{tabular}

$X$ : not identified

* percent of the total amount of fatty acids in the sample

TABLE 2 - Lipid extract (g. $\mathrm{Kg}^{-1} \mathrm{DM}$ ) and fatty acid composition of Saccharomyces cerevisiae M-300-A grown in molasses medium under anaerobic fermentation.

\begin{tabular}{cccc}
\hline & \multicolumn{3}{c}{ MOLASSES } \\
\cline { 2 - 4 } Fatty Acid * & 1 & 3 & 9 \\
\hline $10: 0$ & 1.9 & 3.0 & 0.4 \\
$10: 1$ & 0.2 & 0.5 & 0.1 \\
$12: 0$ & 1.8 & 3.3 & 0.7 \\
$12: 1$ & 0.1 & 0.1 & 0.1 \\
$14: 0$ & 0.7 & 0.7 & 0.2 \\
$14: 1$ & 0.2 & 0.2 & 0.2 \\
$16: 0$ & 29.9 & 33.5 & 32.0 \\
$16: 1$ & 5.3 & 8.7 & 2.4 \\
$18: 0$ & 13.8 & 14.6 & 10.2 \\
$18: 1$ & 8.5 & 8.4 & 12.3 \\
$18: 2$ & 30.7 & 22.4 & 34.1 \\
$18: 3$ & 6.7 & 4.3 & 7.4 \\
\hline Lipid extract & 21.64 & 16.65 & 27.62 \\
\hline \hline
\end{tabular}

* percent of the total amount of fatty acids in the sample 
TABLE 3 - Lipid extract ( $\mathrm{g} \cdot \mathrm{Kg}^{-1} \mathrm{DM}$ ) and fatty acid composition of Saccharomyces uvarum Iz-1904 grown in molasses medium under anaerobic fermentation.

\begin{tabular}{cccc}
\hline \hline & \multicolumn{3}{c}{ MOLASSES } \\
\cline { 2 - 4 } Fatty Acid * & 1 & 3 & 9 \\
\hline $10: 0$ & 0.7 & 1.2 & 0.3 \\
$10: 1$ & 0.1 & 0.1 & ND \\
$12: 0$ & 1.4 & 3.3 & 1.0 \\
$14: 0$ & 1.2 & 1.4 & 11 \\
$14: 1$ & 0.4 & 0.4 & 04 \\
$16: 0$ & 35.3 & 37.8 & 34.1 \\
$16: 1$ & 3.9 & 7.2 & 1.8 \\
$18: 0$ & 9.0 & 10.3 & 7.4 \\
$18: 1$ & 9.7 & 9.0 & 12.1 \\
$18: 2$ & 33.8 & 24.8 & 36.0 \\
$18: 3$ & 4.5 & 4.4 & 5.7 \\
\hline Lipid extract & 23.71 & 20.16 & 31.12 \\
\hline \hline
\end{tabular}

* percent of the total amount of fatty acids in the sample

\section{ACKNOWLEDGEMENTS}

This work was supported by "Assessoria em Fermentação Alcoólica" (FERMENTEC), Brazil. The author would also like to thank Prof. João Nunes Nogueira for reading and correcting this manuscript and $\mathrm{Mr}$. Luis Lucatti for technical assistance.

\section{REFERENCES}

ACKMAN, R.G. Structure and retention time in the gasliquid chromatography of unsaturated fatty acids on polyester substrates. Nature, london, v.194, p.970$971,1962$.

BALCH, R.T. The lipids of sugarcane. In: HONIG, P. (Ed.). Principles of sugar technology. Amsterdan: Elsevier, 1953. p.196-213.

BENDOVÁ, O.; RICHETER, V.; JANDEROVÁ, B.; HAUSLER, J. Identification of industrial yeast strains of Saccharomyces cerevisiae by fatty acid profiles. Applied of Microbiological and Biotechnology, Berlin, v.35, p.810-812, 1991.
BLOOMFIELD, D.K.; BLOCH, K. The formation of unsaturated fatty acids. Joumal of Biological Chemistry, Baltimore, v.235, n.2, p.337-345, 1960.

BOWMAN, G.L. \& VEUM, T.L. Saccharomyces cerevisiae yeast culture in growing finishing swine diets. Journal of Animal Science, Albany, v.37, n.1, p.72-74, 1973.

FOLCH, J. LESS, M; SLOANE-STANBY. G.H.S. A simple method for the isolation and purification of total lipids from animal tissues. Joumal of Biological Chemistry, Baltimore, v.226, p.497-509, 1957.

GURR, M.I. Role of Fat in Food and Nutrition. London: Elsevier Applied Science, 1984. p.94-116.

GUTIERREZ, L.E.; ANNICCHINO, A.V.K.O.; LUCATTI, L. Capacidade fermentativa de Saccharomyces cerevisiae enriquecida com ácidos graxos. Anais da Escola Superior de Agricultura "Luiz de Queiroz", Piracicaba, v.47, n.2, p.575-595, 1990. 
GUTIERREZ, L.E. Composição em ácidos graxos e viabilidade celular em Saccharomyces cerevisiae. STAB, Piracicaba, v.9, n.6, p.31-34, 1991.

HARRISON, J.S. Yeast production. Progress Industrial Microbiology, Amsterdan, v.10, p.129-177, 1971.

HARTMAN, L.; LAGO, R.C.A. Rapid preparation of fatty methyl esters from lipids. Lab Practice, v.22, p. $475-476,1973$.

JARDIM, W.R. Alimentos e alimentação do gado bovino. São Paulo: Ed. Agronômica Ceres, p.338, 1976 .

MEE, J.M.L.; BROOKS, C.C; STANLEY, R.W. Amino acid and fatty acid composition of cane molasses. Joumal of Science Food Agricultural, v.30, p.429-432, 1979 .

MORRISON, F.B. Feeds and Feeding. Clinton: Morrison. p.528-536, 1959.

NAGAR-LEGMANN, R. \& MARGALITH, P. A comparative study of the lipid composition of yeasts with different fermentative capacities. Applied of Microbiology and Biotechnology, Berlin, v.26, n.3, p.449-454, 1987 .

ORELLI, V.F.M.; AMORIM, H.V.; ORELLI, A.A.; OLIVEIRA, A.J. Efeito da remoçāo de células sobre o rendimento da fermentação alcoólica por levedura. Revista Microbiologia, São Paulo, v.22, n.2, p.170178, 1991.
RESENDE, M.A.; ALTERTHUM, F. Effect of temperature on the lipid composition of anaerobically grown Saccharomyces cerevisiae. Revista Latinoamericana de Microbiologia, México, v.28, p.345-349, 1986.

SHORLAND, F.B. The comparative aspects of fatty acid ocurrence and distribution In: FLORKIN M; MASON H.S. Comparative biochemistry, New York: Academic Press, 1962, v.3, p.1-102.

SUOMALAINEN, H.; KERANEN, A.J.A. The effect of anaerobic conditions on the synthesis of fatty acids by yeast. Suomen Kemistilehti, Helsink, v.36b, p.88$90,1963$.

THOMAS, D.S.; ROSE, A.H. Inhibitory effect of ethanol on growth and solute accumulation by Saccharomyces cerevisiae as affected by plasmamembrane lipid composition. Archives of Microbiology, Berlin, v.122, p.49-55, 1979.

VANANUVAT, P. Value of yeast for poultry feeds. Critical of the Reviews Food Science Nutricion, Cleveland, v.9, p.325-343, 1977.

Received in May 26, 1993

Accepted in July 16, 1993

Enviado para publicação em 26.05 .93

Aceito para publicação em 16.07 .93 